\title{
PERSEPSI GURU PAUD TERHADAP FAKTOR-FAKTOR YANG MENGHAMBAT DALAM MELAKSANAKAN PEMBELAJARAN DI PAUD SE-KECAMATAN UJAN MAS KABUPATEN KEPAHIANG
}

\author{
PRETY CITRA PRATESI \\ Mahasiswa Pascasarjana Universitas Bengkulu \\ Prettyst48@gmail.com
}

\begin{abstract}
Abstrak
Permasalahan dalam penelitian ini adalah bagaimanakah persepsi guru PAUD terhadap faktor-faktor yang menghambat dalam melaksanakan pembelajaran pada aspek pengelolaan kelas, aspek media dan sumber belajar, aspek metode dan strategi pembelajaran, serta aspek bahan belajar dan penilaian pembelajaran. Tujuan penelitian ini adalah untuk mendeskripsikan persepsi guru PAUD terhadap faktor-faktor yang menghambat dalam melaksanakan pembelajaran. Metode yang digunakan dalam penelitian ini adalah deskriptif kuantitatif. Penelitian ini menggunakan teknik Total Sampling, dengan sampel yang berjumlah 34 guru PAUD di Kecamatan Ujan Mas. Data penelitian diperoleh dengan menggunakan kuisioner. Berdasarkan hasil dan pembahasan hasil penelitian maka dapat disimpulkan sebagai berikut: 1. Persepsi guru PAUD pada aspek pengelolaan kelas tergolong tinggi, 2. Persepsi guru PAUD pada aspek media dan sumber belajar tergolong tinggi, 3. Persepsi guru PAUD pada aspek metode dan strategi pembelajaran tergolong tinggi, dan 4. Persepsi guru PAUD pada aspek bahan belajar dan penilaian pembelajaran tergolong sangat tinggi. Dari kesimpulan ini, disarankan kepada guru untuk mengikuti pelatihan-pelatihan untuk meningkatkan kompetensi melaksanakan pembelajaran.
\end{abstract}

Kata Kunci: persepsi, guru PAUD, pembelajaran

\section{EARLY CHILDHOOD EDUCATION TEACHERS PERCEPTIONS OF FACTORS THAT INHIBIT LEARNING IMPLEMENTING AT PAUD IN UJAN MAS DISTRICT KEPAHIANG REGION}

\begin{abstract}
The problem in this research is how early childhood teachers' perceptions of the factors that hinder the learning implement in classroom management aspects, media and learning resources aspects, methods and learning strategies aspects, as well as learning materials and assessment of learning aspects. The purpose of this study was to describe early childhood teachers' perceptions of the factors that hinder the learning implement. The method used in this research is quantitative descriptive. This study used a total sampling technique, with 34 early childhood teachers in Ujan Mas District as samples. Data were obtained by using questionnaire. Based on the results and discussion of research results can be summarized as follows: 1. Perception of early childhood teachers in classroom management aspect is high, 2. Perception of early childhood teachers on aspects of media and learning resources is high, 3. Perception of early childhood teachers on aspects of teaching methods and strategies classified high, and 4. Perceptions of early childhood teachers on aspects of learning materials and learning assessment of classified as very high. From this conclusion, it
\end{abstract}


Jurnal Pendidikan Islam Anak Usia Dini

is suggested to teachers to attend trainings to improve the competence of implementing learning.

Keyword: perceptions, Early Childhood Education teacher, learning

\section{Pendahuluan}

Sebagaimana dicantumkan dalam Peraturan Pemerintah Nomor 19 Tahun 2005 tentang Standar Nasional Pendidikan, yang dirumuskan dengan mempertimbangkan karakteristik penyelenggaraan PAUD, Standar PAUD terdiri atas 4 kelompok, yaitu: (1) Standar Tingkat pencapaian perkembangan; (2) Standar pendidik dan tenaga kependidikan; (3) standar isi, proses, dan penilaian; dan (4) standar sarana, prasarana, pengelolaan, dan pembiayaan.

Pada standar pendidikan dan tenaga kependidikan, dinyatakan bahwa seorang pendidik PAUD harus memiliki kualifikasi pendidikan minimal S1. Sehingga pendidik yang belum memiliki kualifikasi tersebut tidak termasuk dalam strandar pendidik, melainkan tenaga kependidikan lainnya seperti guru pendamping maupun pengasuh. Namun dalam penelitian ini penulis mengacu pada Permendiknas No. 58 tahun 2009, tanpa melihat kualifikasi pendidikannya, maka setiap profesional yang bertugas merencanakan, melaksanakan proses pembelajaran, dan menilai hasil pembelajaran, serta melakukan pembimbingan, pengasuhan, dan perlindungan anak didik dapat dinyatakan sebagai guru PAUD.

Fadlillah (2012:87) menyebutkan bahwa Kompetensi merupakan salah satu kualifikasi guru yang terpenting. Bila kompetensi ini tidak ada pada diri seorang guru, maka ia tidak akan berkompeten dalam melakukan tugasnya dan hasilnya pun tidak akan optimal. Kompetensi yang hendaknya dimiliki oleh guru antara lain kompetensi pedagogi, kompetensi kepribadian, kompetensi sosial, dan kompetensi profesional.

Menurut Fadlillah (2012: 131) Proses pembelajaran merupakan suatu hal yang paling penting dalam kegiatan pendidikan. Pada tahap inilah materi yang menjadi tujuan pendidikan disampaikan atau diberikan kepada peserta didik. Oleh karenanya, pelaksanaan pembelajaran perlu dirancang dan diformat dengan sebaik-baiknya, sehingga pada pelaksanaannya, pembelajaran dapat berlangsung dengan baik dan apa yang disampaikan terserap dan dipahami dengan baik dan mendapatkan hasil yang optimal.

Menurut Rusman dalam Fadlillah (2012:150), kegiatan pembelajaran ditandai oleh adanya kegiatan pengelolaan kelas, penggunaan media dan sumber 
belajar, dan penggunaan metode dan strategi pembelajaran. Pengelolaan kelas meliputi mengatur tata ruang kelas untuk pengajaran dan menciptakan iklim belajar mengajar yang serasi. Ini merupakan langkah awal dalam membentuk kegiatan pembelajaran. Selanjutnya penggunaan media dan sumber belajar yang berperan penting untuk menyampaikan isi pembelajaran pada anak. Media belajar terdiri dari media yang bersifat visual, audio, dan audio-visual. Penggunaan media yang bervariasi akan membuat anak merasa lebih tertantang dan tidak bosan dalam mengikuti kegiatan pembelajaran yang disampaikan guru. Penggunaan metode dan strategi pembelajaran yang dipilih oleh guru berpengaruh dalam pencapaian keberhasilan pembelajaran. Pelaksanaan pembelajaran di pendidikan anak usia dini hendaknya disesuaikan dengan keadaan dan karakteristik anak. Pembelajaran biasanya dibuat menyenangkan sehingga anak merasa nyaman dan dapat mengikuti pembelajaran dengan maksimal.

Tidak dapat dipungkiri, dalam melaksanakan pembelajaran di kelas, guru tentu menemui hambatan-hambatan pada setiap aspeknya. Dalam aspek pengelolaan kelas dan penciptaan iklim kelas, hambatan dapat timbul pada saat pengaturan pola tempat duduk siswa, peletakan perlengkapan kelas, maupun dalam sirkulasi udara dan pencahayaan yang disebabkan kondisi sarana dan prasaran yang kurang mendukung dan atau kurangnya ide guru untuk menciptakan lingkungan belajar yang aman dan nyaman. Hambatan juga dapat dialami guru dalam membina perilaku anak didik karena kurang mampu menciptakan iklim pembelajaran serta hubungan yang kurang harmonis dengan peserta didik. Pada aspek penggunaan media dan sumber belajar, hambatan seringkali berupa kurangnya media dan sumber yang tersedia atau kurangnya keterampilan guru dalam memilih dan menggunakan media dan sumber belajar yang ada. Hambatan lainya yang dialami oleh guru dapat berasal dari aspek metode dan penilaian pembelajaran yang digunakan. Hambatan ini berkaitan dengan kurangnya ketepatan dalam pemilihan dan penggunaan metode dan stategi pembelajaran serta alat penilaian dalam proses pelaksanaan pembelajaran.

Munculnya hambatan-hambatan tersebut dipicu oleh faktor-faktor yang berasal dari berbagai pihak, baik itu siswa, guru, sekolah, masyarakat, maupun lembaga yang terkait di dalamnya. Untuk mengetahui hambatan apa saja yang dialami oleh guru dalam melaksanakan 
pembelajaran perlu juga diketahui faktorfaktor yang mempengaruhi munculnya hambatan tersebut.

\section{Kajian Pustaka}

Persepsi merupakan suatu proses yang didahului oleh proses penginderaan, yaitu merupakan proses diterimanya stimulus oleh individu melalui alat indera atau disebut juga proses sensoris (Walgito, 2004:87). Persepsi guru PAUD adalah pendapat/tanggapan guru PAUD yang dipengaruhi oleh pengetahuan, kemampuan berpikir, perasaan dan pengalaman-pengalaman, dan bersifat individual. Karena itu, persepsi guru PAUD mengenai hambatan-hambatan yang dialaminya pada saat melaksanakan pembelajaran di kelas juga berbeda-beda. Meski aspek yang mengalami hambatan sama, namun setiap guru memiliki pendapat yang berbeda tentang faktorfaktor yang menghambat dalam pelaksanaan pembelajaran.

Menurut Fadlillah (2012: 67) pembelajaran anak usia dini ialah proses pembelajaran yang ditujukan untuk anak usia 0-6 atau 0-8 tahun. Pembelajaran ini dimaksudkan supaya anak usia dini dapat memperoleh ilmu pengetahuan dan dapat mengembangkan potensi yang dimilikinya dengan optimal. Pelaksanaan pembelajaran meliputi kegiatan dari membuka sampai menutup pelajaran. Kegiatan pembelajaran ditandai oleh adanya kegiatan pengelolaan kelas, penggunaan media dan sumber belajar, dan penggunaan metode dan strategi pembelajaran. Pengelolaan kelas meliputi mengatur tata ruang kelas untuk pengajaran dan menciptakan iklim belajar mengajar yang serasi. Selanjutnya penggunaan media dan sumber belajar yang berperan penting untuk menyampaikan isi pembelajaran pada anak. Penggunaan metode dan strategi pembelajaran yang dipilih oleh guru berpengaruh dalam pencapaian keberhasilan pembelajaran. Di PAUD penyampaian bahan ajar dilakukan sesuai dengan tema-tema pembelajaran yang telah ditentukan kurikulum. Bahan ajar yang dipilih oleh guru hendaknya disesuaikan pada tema belajar yang pelajari. Guru harus memahami konsep penilaian sehingga guru mampu merancang dan memilih penilaian yang sesuai dengan tujuan pembelajaran, materi, dan aktivitas anak.

\section{Metode Penelitian}

Metode penelitian yang digunakan dalam penelitian ini adalah metode deskriptif kuantitatif. Metode deskriptif diartikan sebagai penelitian yang bermaksud untuk memaparkan data dengan 
menganalisis data yang diperoleh sehingga mendapatkan gambaran yang jelas. Metode kuantitatif digunakan dalam penelitian ini untuk melihat seberapa besar persentase hambatan yang dialami oleh guru PAUD dalam melaksanakan pembelajaran (Rahidiasmara, 2003:25).

\section{Hasil Penelitian}

Berdasarkan hasil penelitian, menunjukkan bahwa persepsi guru terhadap faktor-faktor yang menghambat dalam melaksanakan pembelajaran pada aspek pengelolaan kelas, media dan sumber pembelajaran, metode dan strategi pembelajaran serta bahan belajar dan penilaian hasil pembelajaran cukup tinggi. Persentase guru yang mengalami hambatan paling rendah terdapat pada aspek pengelolaan kelas yaitu $75 \%$, sedangkan persentasi hambatan tertinggi pada aspek bahan belajar dan penilaian pembelajaran $(81 \%)$. Sementara pada aspek metode dan strategi pembelajaran serta aspek bahan belajar dan penilaian pembelajaran memiliki persentase yang sama, yaitu $79 \%$. Tingginya angka persentase persepsi guru terhadap faktor yang menghambat dalam melaksanakan pembelajaran di PAUD juga dipengaruhi oleh kualifikasi pendidikan guru. Mengingat kondisi kualifikasi pendidikan guru PAUD di kecamatan Ujan Mas masih lebih banyak guru tamatan SMA daripada S1, membuat angka persepsi guru yang mengalami hambatan menjadi lebih tinggi.

Hambatan dalam pengelolaan kelas yang banyak dialami guru adalah penataan ruang kelas dan pembinaan perilaku anak didik. Kurangnya pengetahuan dan kemampuan dalam menggunakan media dan sumber yang ada juga menjadi salah satu faktor penyebab munculnya hambatan, tidak hanya disebabkan oleh kurang tersedianya media dan sumber yang dibutuhkan, namun juga kurangnya dana dan keterampilan guru untuk mengkreasikan media. Pada aspek metode dan strategi pembelajaran, faktor yang meyebabkan munculnya hambatan berasal dari dari guru seperti kurang memahami dan menguasai metode dan strategi yang digunakan. Pada aspek bahan belajar, faktor yang menghambat dari guru yaitu kesulitan dalam mengembangkan bahan ajar, sehingga bahan ajar yang digunakan sulit untuk dipahami oleh anak, bahan ajar yang dikembangkan tidak sesuai dengan kemampuan anak. Sedangkan pada aspek penilaian pembelajaran, hambatan paling banyak muncul dari guru, seperti kurang pemahaman mengenai teknik-teknik penilaian, sehingga instrumen penilaian yang digunakan kurang tepat. 
Daftar Pustaka

Arikunto, Suharsimi. 2010. Prosedur Penelitian Suatu Pendekatan Praktik. Jakarta: Renika Cipta

Dahar, Ratna Wilis. 2011. Teori-Teori Belajar dan Pembelajaran. Jakarta: Erlangga.

Darmawan \& Permasih. 2011. Kurikulum dan Pembelajaran. Bandung: Universitas Pendidikan Indonesia.

Djamarah, Syaiful Bahri dan Aswan Zain. 2010. Strategi Belajar Mengajar. Jakarta: PT. Rineka Cipta.

Fadlillah, Muhammad. 2012. Desain Pembelajaran PAUD: Tinjauan Teoritik dan Praktik. Jogjakarta: Ar-Ruzz Media.

Fariani, Denny. 2013. Hubungan Pola Asuh Orangtua Terhadap Sosial Emosional Anak Usia Dini Di Taman Kanak-Kanak Al-Muhajirin Kota Bengkulu. Skripsi. Bengkulu: Universitas Bengkulu.

Fathono \& Riyana. 2011. Kurikulum dan Pembelajaran. Bandung: Universitas Pendidikan Indonesia.

Hiramawati, Ratna. 2005. Problematik Pelaksanaan Pembelajaran Bahasa Indonesia Di Kelas 1 SD N 36 Kota Bengkulu. Skripsi. Bengkulu: Universitas Bengkulu.

Kenedi, Dahnan. 2002. Identifikasi Masalah Dalam Pengajaran $\mathrm{Ka}$ Ga-Ngadi SD Negeri SeKecamatanrimbo Pengadang. Skripsi. Bengkulu: Universitas Bengkulu.

Levin, James \& James F. Nolan. Tanpa tahun. Principles of Classroom
Management. USA: Allyn \&

Bacon. (www.abacon.com)

Mariyana, Rita. 2005. Strategi Pengelolaan Lingkungan Belajar Di Taman Kanak-Kanak. Jakarta: Depdiknas.

Morrison, George S. 2012. Dasar-Dasar Pendidikan Anak Usia Dini. Jakarta: PT. Indeks.

N.K, Reostiyah. 2008. Strategi Belajar Mengajar. Jakarta: Rineka Cipta.

Narbuko, cholid dan Ahmadi, Abu. 2007. Metodologi Penelitian. Jakarta: PT. Bumi Aksara.

Patmonodewo, Soemiarti. 2000. Pendidikan Anak Prasekolah. Jakarta: PT. Rineka Cipta

Putra, Nusa dan Ninin Dwilestari. 2012. Penelitian Kualitatif PAUD. Jakarta: PT. Raja Grafindo Persada.

Rusdinal dan Elizar. 2005. Pengelolaan Kelas Di Taman Kanak-Kanak. Jakarta: Depdiknas.

Sugiyono. 2013. Metodologi Penelitian Admistrasi: Dilengkapi dengan Metode R\&D. Bandung: Alfabeta.

Sunhaji.2009.Strategi Pembelajaran, Konsep Dasar, Metode, dan Aplikasi dalam Proses Belajar Mengajar. Yogyakarta: Grafindo Litera Media.

Susita, Eka. 2001. Identifikasi Hambatan Dan Kesulitan Yang Dialami Guru Pada Pelaksanaan Pembelajaran Fisika Di SMU N 1 Kota Bengkulu. Skripsi. Bengkulu: Universitas Bengkulu. 
Jurnal Pendidikan Islam Anak Usia Dini

Suyadi. 2009. Psikologi Belajar PAUD. Yogyakarta: PT. Pedagogia.

Suyanto, Slamet. 2005. Pembelajaran Untuk Anak PAUD. Jakarta: Depdiknas.

Pendidikan Anak Usia Dini.
Jogjakarta: Hikayat.

Suyitno, Imam. 2011. Memahami Tindakan Pembelajaran. Bandung: PT. Refika Aditama.

Syah, Muhibbin. 2011. Psikologi Belajar. Jakarta: Rajawali Pers.

Tim pengembang MKDP Kurikulum dan Pembelajaran. 2011. Kurikulum dan Pembelajaran. Jakarta: PT. Raja Grafindo Persada.

Uno, Hamzah B. Perencanaan Pembelajaran. 2012. Jakarta: PT. Bumi Aksara.

Yulaelawati, Ella. 2007. Kurikulum dan Pembelajaran: Filosofi, Teori, dan Aplikasi. Jakarta: Pakar Raya.

Yus, Anita. 2012. Model Pendidikan Anak Usia Dini. Jakarata: Kencana.

$\begin{array}{lrr}\text { Perkembangan } 2005 . & \text { Penilaian } \\ \text { Taman } & \text { Belajar Anak } \\ \text { Jakarta:Depdiknas. Kanak-Kanak. }\end{array}$

